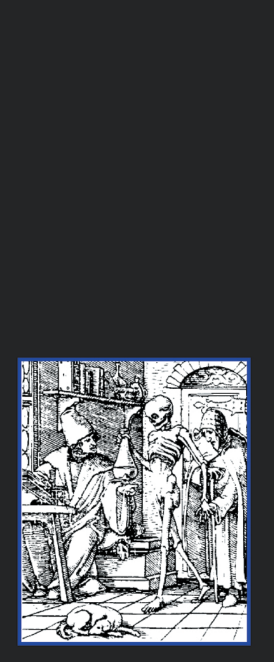

THE HISTORY

OF MEDICINE

IN CONTEXT
A Cultural History of

Medical Vitalism in

\section{Enlightenment}

Montpellier

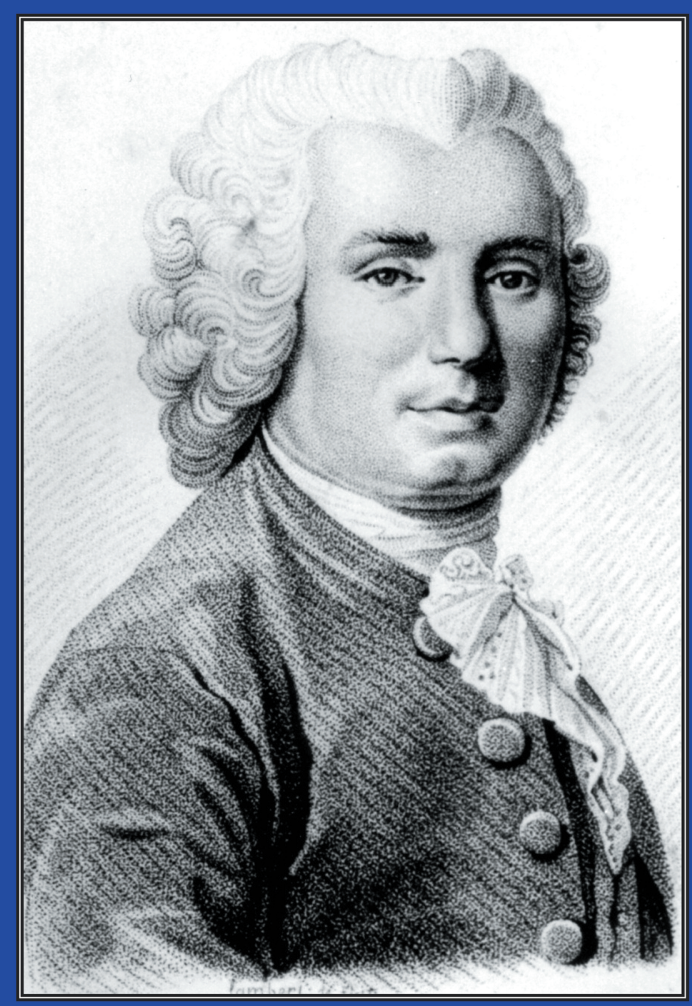

Elizabeth A. Williams

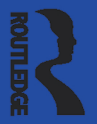




\section{A Cultural History of Medical Vitalism in Enlightenment Montpellier}




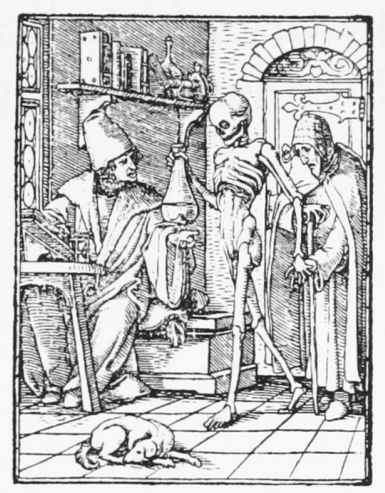

The History of Medicine in Context

Series Editors: Andrew Cunningham and Ole Peter Grell

Department of History and Philosophy of Science

University of Cambridge

Department of History

The Open University

Titles in this series include:

Medicine and Charity in Georgian Bath:

A Social History of the General Infirmary, c. 1739-1830

Anne Borsay

The Nurse Apprentice, 1860-1977

Ann Bradshaw

The Return of Epidemics:

Health and Society in Peru during the Twentieth Century.

Marcos Cueto

Reinventing Hippocrates

Edited by David Cantor

Health Care and Poor Relief in 18th

and 19th Century Northern Europe

Edited by Ole Peter Grell, Andrew Cunningham and Robert Jütte 


\title{
A Cultural History of Medical Vitalism in Enlightenment Montpellier
}

\author{
ELIZABETH A. WILLIAMS
}

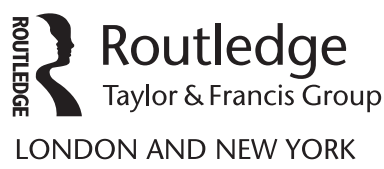


First published 2003 by Ashgate Publishing

Published 2016 by Routledge

2 Park Square, Milton Park, Abingdon, Oxon OX14 4RN

711 Third Avenue, New York, NY 10017, USA

Routledge is an imprint of the Taylor \&o Francis Group, an informa business

Copyright ㅇ Elizabeth A. Williams, 2003

Elizabeth A. Williams has asserted her moral right under the Copyright, Designs and Patents Act, 1988, to be identified as the author of this work.

All rights reserved. No part of this book may be reprinted or reproduced or utilised in any form or by any electronic, mechanical, or other means, now known or hereafter invented, including photocopying and recording, or in any information storage or retrieval system, without permission in writing from the publishers.

Notice:

Product or corporate names may be trademarks or registered trademarks, and are used only for identification and explanation without intent to infringe.

British Library Cataloguing in Publication Data

Williams, Elizabeth A. (Elizabeth Ann), 1950-

A cultural history of medical vitalism in Enlightenment

Montpellier. - (The history of medicine in context)

1. Medicine - France - Montpellier - History - 18th century

2. Medicine - Philosophy 3. Vitalism 4. Enlightenment - France

- Montpellier

I. Title

$610.9^{\prime} 4484^{\prime} 09033$

Library of Congress Cataloging-in-Publication Data

Williams, Elizabeth A. (Elizabeth Ann), 1950-

A cultural history of medical vitalism in enlightenment Montpellier / Elizabeth A. Williams.

p. $\mathrm{cm}$. - (The history of medicine in context)

Includes bibliographical references.

ISBN 0-7546-0881-6 (alk. paper)

1. Medicine - France - Montpellier - History. 2. Vitalism. I. Title. II. Series.

R506.M66 W54 2002

610'.944'84-dc21

2002019417

ISBN 13: 978-0-7546-0881-3 (hbk) 
To Grace Marie Williams and in memory of

Fred Neff Williams (1915-85) 
$\Longrightarrow$ Taylor \& Francis

Taylor \& Francis Group

http://taylorandfrancis.com 


\section{Contents}

Acknowledgments $\quad$ ix

A Note on Translation $\quad \mathbf{x}$

Abbreviations $\quad$ xi

Introduction 1

1 A Medical Town: Montpellier in the Eighteenth Century 16 At the "elbow" of the south $\quad 18$

University and town $\quad 19$

The gardens 25

Promoting and disseminating knowledge $\quad 26$

In the hospitals of Montpellier 31

Practice and practitioners $\quad 35$

$\begin{array}{ll}\text { The waters } & 37\end{array}$

2 A University in the Enlightenment: The University of Medicine of Montpellier $\quad 50$

Institutional hierarchy $\quad 52$

Professors and students $\quad 56$

Student life $\quad 63$

$\begin{array}{ll}\text { The teachers of Bordeu } & 67\end{array}$

3 Boissier de Sauvages and the Emergence of Vitalism in $\begin{array}{ll}\text { Montpellier } & 80\end{array}$

Against Descartes: Sauvages's early career $\quad 81$

Predictable and unpredictable remedies $\quad 86$

Sauvages's nosology $\quad 90$

Pathology and physiology 93

Forces, faculties, and the action of the soul 95

$\begin{array}{lr}\text { Classifying disease } & 101\end{array}$

4 The Ascent to Paris: Montpellier Physicians in the Capital of Enlightenment

"This vile country"

"Hommes du Midi" in Paris $\quad 115$

The lure of surgery 116

Students again $\quad 118$

The Montpellier Encyclopedists $\quad 120$ 
Montpelliérains and Paris medical journalism

Vitalism in the salon

Montpellier and the court

5 Vitalism and the Encyclopedist Movement

Celebrating Béarn

A family collaboration in Paris

Vital force in the body

Vitalism in the Encyclopédie

Medicine and chemistry

Barthez as Encyclopedist

Vitalists and materialists

6 Time of Troubles: The University-Court Connection in the late Ancien Régime

Untenable practices

At war with the town doctors

The clinic thwarted

A world away: Bordeu at court

7 Semiotics, Smallpox, Sex: From the Practical to the

Philosophical in Vitalist Medicine

Semiotics and the search for certainty

"A frightful and treacherous malady"

"Practical medicine" in the Encyclopédie

Vital variability: the case of women

8 Barthez and the "Science of Man" 255

Infinity of ills, infinity of cures $\quad 257$

$\begin{array}{ll}\text { The vital principle } & 260\end{array}$

Forces of the animal economy $\quad 265$

"Modifications" of the vital principle: temperament and age 271

Barthez and the "vitalist sect" 275

9 Vitalism in the Late Enlightenment 28-

The reception of Barthez's synthesis $\quad 290$

Montpellier and the Société royale de médecine 293

Vitalism and Mesmerism

Conclusion: The End of the Enlightenment and the Eclipse of Montpellier

Select Bibliography $\quad 335$

Index 


\section{Acknowledgments}

Many people and institutions helped in the preparation of this book. I am happy for the opportunity to express my gratitude to the librarians and archivists of the following institutions: in France, the Bibliothèque de la Faculté de Médecine de Montpellier, the Archives départementales de l'Hérault, the Bibliothèque de la Ville de Montpellier, the Bibliothèque de France, the Académie nationale de Médecine, and the Bibliothèque de la Faculté de Médecine de Paris; in Britain, the British Library, the Wellcome Institute for the History of Medicine, and the library of the University of Edinburgh; and in the United States, the National Library of Medicine and the Edmon Low Library at Oklahoma State University. Financial assistance was provided by the National Science Foundation, the Oklahoma Humanities Council, and the College of Arts and Sciences and Department of History at Oklahoma State University.

Thanks go also to the many colleagues with whom I discussed the problems and issues addressed in this study, and especially to Robert Mayer, Robert A. Nye, Kathleen Wellman, and the anonymous readers for insightful comments on the manuscript. I regret the flaws that remain despite their good advice. I am grateful too for the help of the editorial staff at Ashgate, especially Andrew Cunningham. Special thanks go to Marsha Richmond for her encouragement and help at a key moment, and to Susan Oliver for expert clerical assistance.

The gratitude I owe my parents is expressed in a small way in the dedication. I do not know how to thank Robert, Eleanor, and Susanna, who help me in everything. They join me, finally, in expressing deep gratitude to our friends in Montpellier, especially Françoise and Hubert Graafland, for the great warmth and generosity with which they welcomed us to the Midi. 


\section{A Note on Translation}

All translations from the French are mine unless otherwise noted. 


\section{Abbreviations}

$\begin{array}{ll}\text { ADH } & \text { Archives départementales de l'Hérault } \\ \text { AFMM } & \text { Archives de la Faculté de Médecine de Montpellier } \\ \text { APSRSM } & \begin{array}{l}\text { Assemblée publique de la Société royale des sciences } \\ \text { de Montpellier }\end{array} \\ \text { Arch.SRM } & \text { Archives de la Société royale de médecine } \\ \text { BHM } & \text { Bulletin of the History of Medicine } \\ \text { Biog.Med. } & \text { Biographie médicale par ordre chronologique } \\ \text { BVM } & \text { Bibliothèque de la Ville de Montpellier } \\ \text { DBF } & \text { Dictionnaire de biographie française } \\ \text { DSB } & \text { Dictionary of Scientific Biography } \\ \text { DSM:BM } & \text { Dictionnaire des sciences médicales: Biographie } \\ & \text { médicale } \\ \text { Encyclopédie } & \text { Encyclopédie des arts, sciences et métiers } \\ \text { HMSRM } & \text { Histoire et mémoires de la Société royale de } \\ & \text { médecine } \\ \text { HSRSM } & \text { Histoire de la Société royale des sciences de } \\ & \text { Montpellier } \\ \text { JHM } & \text { Journal of the History of Medicine and Allied } \\ & \text { Sciences } \\ \text { JMCP } & \text { Journal de médecine, chirurgie et pharmacie } \\ \text { JS } & \text { Journal des savans } \\ \text { MH } & \text { Medical History } \\ \text { Monsp.Hipp. } & \text { Monspeliensis Hippocrates } \\ \text { MT } & \text { Mémoires pour servir à l'histoire des sciences et des } \\ & \text { arts (Mémoires de Trévoux) } \\ \text { O.C.Bordeu } & \text { Oeuvres complètes de Bordeu } \\ \text { RHS } & \text { Revue d'histoire des sciences }\end{array}$


$\Longrightarrow$ Taylor \& Francis

Taylor \& Francis Group

http://taylorandfrancis.com 


\section{Introduction}

A generation ago historical scholarship conveyed a serene, untroubled view of the Enlightenment. As portrayed by scholars of the 1960s and 1970s, the Enlightenment was a movement based in France and England; secular, even "pagan" in temper; based unproblematically on scientific method; and devoted to reform and progress. ${ }^{1}$ In the intervening years, however, these familiar features of the Enlightenment have been questioned by Enlightenment revisionists inspired by diverse theoretical enterprises, chief among them the work of the Frankfurt School and of Michel Foucault. Enlightenment revisionism is perhaps most aptly viewed as a long-term consequence of the Holocaust, the rationalized attempt by leaders of a putatively enlightened nation to destroy a branch of the human race. Indeed revision got underway amid the Holocaust itself in the famous book by Max Horkheimer and Theodor W. Adorno entitled Dialectic of Enlightenment, written in 1944. ${ }^{2}$ Here emerged the view that would haunt the passages of late twentieth-century scholarship: the Enlightenment as a great movement toward "the world of the administered life," one in which intellect was identified with "that which is inimical to the spirit."

Of the questions raised by this denunciation of Enlightenment, none was, or remains, more crucial than the nature of the Enlightenment heritage in respect to science. Horkheimer and Adorno argued that "not only the pursuit but the meaning of science [had] become problematical" because science ineluctably encouraged an instrumental approach to nature and humanity. Science, they asserted, undergirded all improving movements that "as representatives of power - even if of power for good - ... became historical forces which could be organized, and as such played a bloody role in the true history of the human race: that of the instruments of organization." 4 This attack on the Enlightenment heritage of science followed from the philosophical presuppositions of Horkheimer and Adorno, who saw Enlightenment originating in a drive to self-preservation that produced "blindly pragmatized thought" bereft of "its transcending quality and its relation to truth." Their perspective did not, however, rest on historical investigation of the actual practice of science in Enlightenment Europe. Nor could it have, since at the time of their writing the history of Enlightenment science was little developed. To be sure, the 
Enlightenment had been readily integrated into the positivist history of science elaborated in the nineteenth century. So viewed, the Enlightenment continued the Scientific Revolution and thus stood at the font of subsequent scientific development in the West. But close study of what kind of science was done under the aegis of Enlightenment methods, problems, aims - was in short supply. Nor, given the generally optimistic cast of both history of science and Enlightenment studies in the postwar decades, did the gloomy perspective of Horkheimer and Adorno spur historical investigations that might lend empirical weight to their rethinking of reason, science, and Enlightenment.

By the late 1960s, however, the world had changed and historiography with it, and the Frankfurt School denunciation of Enlightenment and science merged with critiques articulated by scholars identified with poststructuralism, feminism, and postcolonialism. As viewed by such critics, science excludes, marginalizes, and oppresses individuals and groups lying beyond its boundaries of the "normal." According to this perspective, science works in collusion with political, military, and economic power to reinforce relations of dominance and inequality between rich and poor nations, men and women, straights and gays. Although the chief concern of what proponents call "science studies" and detractors call "anti-science" has been the role and power of science in the present, a number of influential historical studies have traced to early science the modalities of exclusion and domination others espied in modern science. ${ }^{6}$ At the same time, attention has shifted away from science in general to the role of particular disciplines in establishing the oppressive character of scientific activity. Thanks in part to the pervasive influence of Michel Foucault and more generally to the threats perceived to emanate from what he called "biopower," medicine has come under especially close scrutiny.' Such scrutiny was perhaps inevitable for, as Peter Gay observed decades ago, the Enlightenment had proclaimed medicine the "most tangible cause for confidence" and derived from medicine crucial elements of the discourse of "perfectibility." The pursuit of perfectibility implied boundless intervention in the habits, way of life, and self-conceptualization of all members of the enlightened society and polity. Such intervention and management was the focus of proliferating discourses of science, pedagogy, and politics, but in important ways medicine was the critical discourse since it alone could promise the improvements in fundamental "constitution" - the interlinked domains of the physical and the moral - that were generally regarded as the foundation of human progress." Thus medicine was called upon to collect, analyze, and use "observations" of the minute particulars of the body, psyche, and 
behavior of, ideally, every citizen of the realm. If Enlightenment physicians were divided on issues of theory and practice, medical discourse was nonetheless monolithic in insisting on the "utility" of medicine to society and polity. ${ }^{10}$ They thus celebrated that very "instrumentality" of reason in which Horkheimer and Adorno perceived the "development toward total integration" at work in the Enlightenment."

While the Frankfurt School critique remained highly abstract, Foucault pursued investigations of specific historical developments in medicine and related sciences. In these inquiries he blasted the foundations of a celebratory Enlightenment historiography by tracing to the keepers of "knowledge" a range of "disciplinary" techniques that defined and circumscribed "the heart, the thoughts, the will, the inclinations." 12 With his historical analyses of medical discourse and institutions Foucault turned the traditional historiography of Enlightenment on its head. What had been triumphs of human learning, striving, and sympathy he viewed as barely disguised strategies of power.

In subsequent decades this Foucauldian perspective on medicine has been elaborated by scholars who have sought, as Foucault did, to fashion a "history of the body" and who have used medical sources to explore such themes as the elaboration of gender constructs and the "normalizing" impulse discernible in aesthetic and learned enterprises of the eighteenth century. ${ }^{13}$ Nonetheless, despite these developments, the view of the Enlightenment that continues to dominate the history of medicine, as opposed to the "history of the body" and related endeavors, is still essentially that of the liberal historiography of the 1960s. Excellent work on Enlightenment medicine has been undertaken in recent decades, especially in augmenting the biographical literature of the principal médecins-philosophes and in extending our understanding of the institutions, social organization, and economics of eighteenthcentury medicine. ${ }^{14}$ But the problem that has dominated Enlightenment revisionism - the dehumanizing potentialities of science - has not yet engaged medical historians. This work undertakes that task by focusing on Montpellier vitalism, the chief intellectual product of one of the leading institutions of Enlightenment medicine. ${ }^{15}$

In Enlightenment France the vitalist physicians of Montpellier were the chief antagonists of the medical framework of the body machine first developed by Descartes and later elaborated by physicians associated with "iatromechanism." 16 In place of the body machine perspective that sought "laws" universally valid for all phenomena, the Montpellier vitalists posited an absolute distinction between living, "organized" being and brute, inert matter. They attributed this life to the action of a 
force, principle, or power whose origin and ontological status were unknowable. They saw life as enabled by the interrelated and harmonious activities of the "body economy" and as engaged in a constant struggle against processes of disharmony, destruction, and disintegration commonly conceived of as illness. They perceived ceaseless interactions of internal disposition and external milieu that eventuated in distinctive human types formed by age, sex, temperament, region, and other powerful influences on the vital economy.

These principles gained lasting recognition for the Montpellier vitalists. Even at moments when vitalism fell into greatest disrepute, historians of life science acknowledged that the Montpellier vitalists especially the two chief theorists Théophile de Bordeu and Paul-Joseph Barthez - merited recognition as the principal French participants in a Europe-wide challenge to mechanist biology and medicine that unfolded in the late eighteenth and early nineteenth centuries. A general history of the sciences initiated by Georges Cuvier, for example, lauded the Montpellier vitalists for their role in demolishing "crude mechanist explanations" of body function and thus opening the way to a refurbished mechanism, built on late-Enlightenment advances in the physical sciences, that eventually vanquished vitalism and cleared the high road to the modern life sciences. ${ }^{7}$

In modern historiography this representation of Montpellier vitalism persists. Its importance has been widely acknowledged; calls for a fuller understanding of its history have been issued. But these judgments have generally been made in reference to the role Montpellier vitalists played in the conceptual history of physiology. ${ }^{18}$ It is certainly not my aim to challenge the view that Montpellier vitalism occupies an important place in the theoretical development of physiology. Nonetheless, I argue here that this approach scarcely hints at the range and discursive power of Montpellier vitalism and fails to explain its role in the Enlightenment as a cultural movement. By contrast, the history of Montpellier vitalism offered in this work explores not only conceptual developments but the institutions and frameworks of communication that constituted its cultural and social setting. In so doing this study demonstrates that Montpellier vitalism constituted an expansive discourse of medicine that exerted broad influence by elaborating a distinctive understanding of the methods and objectives of science. The differences between science as conceived by the Montpellier vitalists and the science usually thought characteristic of the Enlightenment may be suggested by the following dichotomies: 
Model Enlightenment science

universal laws of nature
determinist
grounded in mathematics
experiment and observation
unity of the sciences
anti-teleological
secular/anticlerical
Newtonian
Anglophile
hostile to tradition
metropolitan base

Montpellier vitalism

particular laws of vitality
vitally integrated
anti-mathematical
observation only
autonomy of medicine
teleological
respectful of religion
lukewarm/hostile to Newton
continental
respectful of "Ancients"
regional base

Like all such structuralist exercises, this schema oversimplifies certain issues of filiation and allegiance, but it is nonetheless useful in suggesting patterns that undeniably differentiated the work of the Montpellier vitalists from what has usually been thought to constitute Enlightenment science. ${ }^{19}$

The implications of this vitalist model of science were many and important, chief among them the contribution Montpellier physicians made to the Enlightenment discourse of perfectibility. From the outset, the universalist claim that all human beings were alike in essentials and encompassed within the same trajectory of progress was beset by doubts, uncertainties, and perplexities. These were powerfully encouraged by vitalist medical discourse, which declared efforts to transcend "natural" limits on human improvement futile, even dangerous. Vitalists argued that the pursuit of perfect well-being was chimerical not only for individuals, who invariably suffered from some primordial vital deficiency, but, more importantly, for diverse human "types" - temperamental, regional, sexual, racial - whose vital force was limited, variably channeled, and susceptible only to slight alteration, if any. Accordingly, the Montpellier physicians stand precisely at the origin of those "exclusions" from Enlightenment optimism - women, exotic peoples, manual workers - that have encouraged critics to see in perfectibility, progress, and optimism itself just so many discourses of domination.

The skepticism of the Montpellier vitalists about perfectibility reflected their divergence from general tendencies of Enlightenment scientificity, whose optimism about human prospects historians have linked to a rejection of Christian dualist metaphysics and fatalism in favor of an activist humanism grounded on materialism and 
instrumental rationality. Medicine and the emergent life sciences have been ascribed a crucial role in this regard, with the biology of Diderot often taken as exemplary given his rejection of metaphysics as "contemptible" and his insistence on "a true science of the real." Existing historiography associates the Montpellier vitalists, especially Bordeu, with Diderot's enterprise, and indeed the evidence is strong that it was Montpellier teaching on vital force and sensibility that impelled Diderot, as Jacques Roger puts it, toward "the end of his philosophical reflections on nature." 21 Yet what Montpellier vitalism was and what Diderot made of it are two different subjects. I argue that this perspective obscures not only the vitalists' independent position in Enlightenment science, which offered a third way between the spiritualism of Christian orthodoxy and the materialism of Diderot, but also our understanding of the impact of Enlightenment medicine and life science. The dominant view is that Enlightenment medicine was materialist, radical, and centrally involved in discarding repressive orthodoxies purveyed by Roman Catholicism.22 This study challenges this overgeneralized view, arguing that, although they were fully a part of the Enlightenment, the Montpellier vitalists were suspicious of materialism, sympathetic to religiosity, and inclined to use medical authority not to liberate but to devise new pathological categories and codes of behavior by importing moralizing traditions into medicine. Thus, while I do not claim that Montpellier vitalism constituted the whole of Enlightenment medicine, I do argue that the discourse they created was a broadly influential variant of an Enlightenment science that was more complicated, diverse, and ambiguous in impact than existing representations generally allow.

To explain the emergence and impact of the vitalist model of science, the book seeks to accomplish a number of interrelated objectives. First, I treat Montpellier vitalism not as abstract theory or as a set of disembodied concepts but as a broad discourse of medicine that developed in specific contexts of conversation, debate, publication, and ongoing institutional work and activity. All the physicians studied here were either medical practitioners or professors, and most of them were both; none of them was a man of leisure. Thus these physicians saw patients, taught classes, delivered addresses, conversed in salons, managed institutions, and published for money. Some of them scrambled fairly desperately for a living; all of them strove for honors, perquisites, and recognition. Their intellectual work responded both to problems encountered in hours of reading, reflecting, and writing, and to the practical demands of daily existence as men of learning engaged earnestly in the public life of their time. Thus I have tried, wherever 
possible, to link discursive formulations to situations compounded of intellectual, institutional, and broader sociocultural pressures. In particular, this study seeks to situate Montpellier vitalism in the place that forms part of its very name. It is striking that the literature on Montpellier vitalism takes no notice of the peculiar coupling of place and discourse accomplished by this locution, for Montpellier vitalism constitutes a rare instance where a town has been yoked with a distinctive scientific tradition. This fact points to a crucial feature of the history of Montpellier vitalism, one that ties it to important themes in Enlightenment historiography.

I argue that the construction of "Montpellier vitalism" constitutes an instance of the mobilization of what may be called "local knowledge" learned conventions purposefully associated with ancient local traditions - and, correlatively, that the fate it met illuminates the inner dynamics of the Enlightenment as a movement dedicated to cultural centralization encouraged by discourses of universalizing science, reform, and progress. ${ }^{23}$ Accordingly, this study pays close attention to the rooting of Montpellier vitalism in its place, exploring urban and regional landscape, social and cultural institutions, local loyalties and traditions. In so doing it elucidates a dual process of creation. On the one hand, it explores the efforts of Montpellier physicians to create a medical discourse founded on a "wisdom" peculiarly associated with Montpellier and the Midi. On the other hand, it examines the disposition of outside commentators to perceive a unity in Montpellier medical discourse, whether to the positive end of profiting from its peculiar wisdom or to the negative end of discrediting vitalism by characterizing it as local, and hence dubious, knowledge. Both of these processes - the deliberate construction of regional-discursive identity by Montpelliérains and the attribution of identity by outside observers were gradual and often ambivalent. Parisian commentators on Montpellier, who styled themselves the universal arbiters of the medicine of the realm, were sometimes critical of Montpellier's exclusivism. ${ }^{24}$ For their part, Montpellier physicians were torn between competing options - they could renounce local identity to pursue success beyond the local; use local knowledge as a means of achieving such success; or, an increasingly difficult choice as the century progressed, attempt to function confidently within a local world that nonetheless claimed "parity" with the outside. Thus the discursive creation of "Montpellier vitalism" offers an instance in the history of science and medicine that unexpectedly shares features with the process Benedict Anderson has designated the creation of an "imagined community" - the elaboration of cultural identity in response to changing horizons of cultural 
interchange, chief among them the kind of centralization that itself provokes the construction and privileging of "local knowledge." ${ }^{25}$

One of the most remarkable features of the history of Montpellier vitalism in the Enlightenment, then, is the fashion in which the creators of this medical discourse of "natural" limitations - those established by temperament, class, age, sex, region, and race - themselves encountered unsurpassable limitations on the potentialities of the méridional, an "ethnotype" that vitalist discourse itself helped to create. ${ }^{26}$ This regional stereotype embodied antinomies of north and south, rational and imaginative, cool and hot, controlled and passionate that, in the world of science, could not but work to the cultural disadvantage of the south. A crucial dimension of this story is that these antinomies were strikingly akin to those emphasized in the emergent discourse of the peculiar "sensibility" of women, who, like the hommes $d u$ Midi, were volatile, imaginative, and similarly ill-constructed for the work of reason and science. This kinship was far from accidental: in French medicine the Montpellier vitalists were the premier theoreticians of women's sensibility and they capitalized on their status as méridionaux in asserting a peculiar sympathy with women. Although useful in the professional context of practice among elite women, the risk entailed by such a strategy became apparent when the medicalized discourse of "types" assigned the Midi a perpetually inferior role to Paris in the universalist culture of science just as it encouraged the exclusion of women from public activity in the late Enlightenment. ${ }^{27}$

Another objective of the study, one that at first glance might seem to contradict this emphasis on the local, is to "delocalize" Montpellier vitalism by showing how its local history was linked to developments in Paris. Although paradoxical, it is a salient fact of the history of cultural regionalism that "local knowledge" takes form and assumes significance only in relation to a metropole. Thus this study considers the Montpellier vitalists at work both in Montpellier, where they were trained and where they registered the peculiar local influences of town and region, and in Paris, where they went to seek their fortunes and where any French cultural product had necessarily to be purveyed and sustained. For the most part, the existing historiography of Montpellier vitalism fails to integrate developments in Paris with those in Montpellier. Either Montpellier vitalism is linked to intellectual currents in the capital, or it is lodged exclusively within the context of Montpellier itself. ${ }^{28}$ Each of these perspectives is faulty: "Montpellier vitalism" developed in Montpellier and it developed in Paris, and its history must encompass developments in both locales.

This blended Montpellier-Paris perspective is essential both to an 
accurate history of Montpellier vitalism itself and to an understanding of its place in the Enlightenment. One of the reigning assumptions about the Enlightenment is that it unfolded only in progressive, modernizing institutional and sociocultural contexts, those created by the precursor movements of Renaissance humanism and the Scientific Revolution, or the new social nexus, emergent in the capital, of cafés, periodical press, and masonic lodges. Institutions associated peculiarly with the Ancien Régime have been correspondingly denigrated. This judgment has been made at the expense of the universities and especially of the court, which has been treated as the site of everything frivolous and lascivious in the eighteenth century but almost never as a locus for serious intellectual or cultural work. ${ }^{29}$ This study does not aim entirely to overthrow such assessments. But it does examine the close relation that tied the University of Medicine of Montpellier to the court and it does explore the strong influence that these ancient institutions exerted on the development of vitalism. In so doing it seeks to modify the existing view of university and court as sites precluding dynamic cultural activity and thus to argue against the dichotomy of "Ancien Régime" and "Enlightenment" that often skews our historical vision of the intellectual and cultural life of the eighteenth century.

In keeping with these objectives, the book is structured as a series of movements back and forth between Montpellier and Paris. The first two chapters examine the social and cultural contours of Montpellier and its region and the institutional and intellectual traditions that characterized the vitalists' premier institutional base, the University of Medicine of Montpellier. These chapters argue for the peculiar "connectedness" of Montpellier physicians to local culture given the intimate, small-town scale of its networks of professional and public activity. The history of Montpellier's learned institutions reveals the uneasy blending there of metropolitan intellectual currents - official Catholicism, Cartesianism, classicism - and local traditions such as the Paracelsian medicine that reached its fullest French development in seventeenth-century Montpellier and the Protestant religiosity that, once powerful throughout Languedoc, was forced underground but never wholly effaced by the centralizing campaigns of the absolutist monarchs. A third Montpellier-focused chapter then examines the work and career of the great "animist" theoretician and nosologist François Boissier de Sauvages, whose teaching exercised lasting sway over the students who were to become the Montpellier vitalists. The unfolding of Sauvages's career illuminates the existence of a shared Protestant medical culture sustained chiefly by epistolary connections with Uppsala, London, Halle, Geneva, and Lyons - that linked Montpellier to physicians 
throughout Europe who refused the dualisms of mind and matter, soul and body, that undergirded the mechanist medicine articulated by followers of Descartes.

Two chapters then examine the vitalists at work in Paris in and among the establishments - at the Jardin royal and the Charité, within the entourage of the duc d'Orléans, and, most important, the Encyclopedist circle - in which the Montpellier physicians found cultural niches in the late 1740s and 1750s. These chapters show the vitalist physicians closely tied for a time to some of the most radical elements of the high Enlightenment but also trace the process by which they ultimately distanced themselves from personalities and activities associated with irreligion and ideological daring. In Chapter 6 the narrative returns, as did most of the vitalist physicians themselves, to Montpellier around 1760, where a "time of troubles" in the University of Medicine and in its relations with the royal court absorbed the energies of the Montpellier-based vitalists and undermined the strength of the institution. Chapter 7 explores the one, and crucial, exception to this pattern, Bordeu, who remained in Paris and became a highly successful practitioner of what the eighteenth century called médecine galante. Focusing his ambitions on practice among highborn women, Bordeu molded vitalist discourse as an instrument for use in this and other culturally charged contexts of "practical medicine." The final two chapters connect developments in both locales in the last decades of the Enlightenment and Ancien Régime. Chapter 8 traces the shift away from practical to "philosophical" medicine effected principally by Barthez, whose synthesis self-consciously offered vitalism as a model of science at odds with the universalizing tendencies characteristic of dominant Enlightenment science. The last chapter traces the demise of the University of Medicine of Montpellier in the late eighteenth century and the related process by which vitalism assumed its peripheral role in French medicine as a kind of anti-science peculiarly useful as a guide to all that was exotic, mad, womanish, passional - in short, the "other" that undercut the optimism of Enlightenment universalism.

Those who seek to speak authoritatively on any subject often get caught in discursive tangles they did not anticipate. This is precisely what happened to the Montpellier vitalists and to vitalism as a discourse. To combat the power of the metropole and establish a science that exemplified its own local wisdom, the vitalists created an alternative to a model of science that they judged misguided. In place of the universalizing procedures of mechanist science, they accented variability and spontaneity. In place of a spurious unity of the sciences, they insisted on medical autonomy. In place of the cosmopolitan, they 
offered local knowledge. These were precarious positions to assume in a learned world that every day lent greater power to both the universalist claims of science - its reliance on uniformly accepted methods, its recognition of unvarying laws of nature, its unshakable unity as an enterprise - and to those institutions, located at the center not just of learning but of all public activity, that embodied and promoted those claims. As the conclusion of this study shows, Montpellier and vitalism suffered accordingly.

Where then does this study finally situate Montpellier vitalism in relation to the Enlightenment, the cultural movement that promoted the universalist ideals just described? Some years ago, when Robert Darnton evaluated the significance of Mesmerism, a medical movement that shared certain affinities with Montpellier vitalism, he concluded that the sway of Mesmer indicated the "end of the Enlightenment in France." 30 In keeping with the new readiness to relinquish the certainties and good cheer of that kind of history, I would argue in respect to Montpellier vitalism that it represented not the end of Enlightenment or some dark underside but one of the ever-present potentialities of Enlightenment science. The Montpellier vitalists resolutely situated themselves among the lumières. They embraced, promoted, and helped to define what they called a "revolution" in medicine. They employed language and methods invariably associated with Enlightenment science. So it is contended here that Montpellier vitalism was fully a part of "the Enlightenment" - a form of Enlightenment science - yet one whose development and characteristic features indicate that the Enlightenment itself was more complicated and diverse in its implications than once was thought.

If Enlightenment science is not what the progressive historiography of the past perceived it to be, what happens in turn to the critique of Enlightenment science that condemned such science precisely for its putative universalism, its crushing normativities? This is not a purely historical question, for if "Enlightenment" is taken to be in important senses equivalent to the rationalizing and universalizing sciences of our own day, Montpellier vitalism may similarly be linked with contemporary "identity politics," and thus the competing claims of all universalizing discourses - medical and otherwise - may be contrasted to those that accent particularity, uniqueness, and the ritually lauded "diversity" of modern cultural politics. In this respect the history of Montpellier vitalism functions as a cautionary tale. The Montpellier vitalists rejected as inapplicable to the human realm the cruelly invariable laws of mechanized nature, substituting in their place a vital lawfulness putatively created by a spontaneous, freely functioning 
individuality. In practice, however, vital "laws" proved peculiarly manipulable by self-styled, expert "observers" who asserted the exclusive authority to judge what was full and what deficient; what was conducive to vital "harmony" and what discordant; what, finally, was normal and what pathological. That they were themselves subsumed to their detriment in antinomies of north and south, center and periphery, rational and passional only proves the autonomous power of discourse which, once established, may lend itself to uses unforeseen by its creators. From this perspective, the contrasting discourses of rationalism and irrationalism, universalism and particularism, determinism and spontaneity, sameness and diversity are all potentially oppressive. That we have devised no practical response to this alarming feature of discourse may mean that we cannot dispel the gloom that engulfed the members of the Frankfurt School, or the unease created by Foucault's recitations of coercion. But it may mean too that we are unafraid to confront the ambiguities yielded by the critical temper, the ongoing "Enlightenment," of our own time.

\section{Notes}

1. Peter Gay, The Enlightenment, vol. 1, The Rise of Modern Paganism, and vol. 2, The Science of Freedom (New York: W.W. Norton, 1966; 1969).

2. Max Horkheimer and Theodor W. Adorno, Dialectic of Enlightenment, trans. John Cumming (New York: Continuum, 1998); all references here are to this edition. The first edition, entitled Dialektik der Aufklärung, was published by the Social Studies Association in New York in 1944.

3. Ibid., $i x, x$.

4. Ibid., xi, 224.

5. Ibid., xiii; see also Jürgen Habermas, "The Entwinement of Myth and Enlightenment: Max Horkheimer and Theodor Adorno," in The Philosophical Discourse of Modernity: Twelve Lectures, trans. Frederick Lawrence (Cambridge, Mass.: MIT Press, 1995), 110-11.

6. In English a seminal work in this field was Edward W. Said, Orientalism (New York: Vintage Books, 1979); other recent works include Londa Schiebinger, Nature's Body: Gender in the Making of Modern Science (Boston: Beacon Press, 1993); id., The Mind Has No Sex? (Cambridge, Mass.: Harvard University Press, 1989); Barbara Maria Stafford, Body Criticism: Imaging the Unseen in Enlightenment Art and Medicine (Cambridge, Mass.: MIT Press, 1993); Sander Gilman, Difference and Patbology: Stereotypes of Sexuality, Race, and Madness (Ithaca, NY: Cornell University Press, 1985).

7. Foucault's critique of medicine was laid out in two major works and in a host of essays, lectures, and interviews; see, in particular, Madness and Civilization: A History of Insanity in the Age of Reason, trans. Richard Howard (New York: Vintage, 1973); The Birth of the Clinic: An Archaeology of Medical Perception, trans. A.M. Sheridan Smith (New 
York: Vintage, 1975); and "The Politics of Health in the Eighteenth Century," in Power/Knowledge: Selected Interviews and Other Writings, 1972-1977, ed. Colin Gordon, trans. Colin Gordon et al. (New York: Pantheon Books, 1972), 166-82.

8. Gay, The Science of Freedom, 12; an overview of recent discussions of perfectibility is found in Dorinda Outram, The Enlightenment (Cambridge: Cambridge University Press, 1995), esp. chaps 5 and 6.

9. Elizabeth A. Williams, The Physical and the Moral: Anthropology, Physiology, and Philosophical Medicine in France, 1750-1850 (New York: Cambridge University Press, 1994).

10. On "utility" as a unifying theme of the Enlightenment, see Lorraine Daston, "Afterword: The Ethos of Enlightenment," in The Sciences in Enlightened Europe, ed. William Clark, Jan Golinski, and Simon Schaffer (Chicago: University of Chicago Press, 1999), 495-504.

11. Horkheimer and Adorno, Dialectic, $\mathbf{x}$.

12. Michel Foucault, Discipline and Punish: The Birth of the Prison, trans. Alan Sheridan (New York: Vintage Books, 1977), 16.

13. Thomas Laqueur, Making Sex: Body and Gender from the Greeks to Freud (Cambridge, Mass.: Harvard University Press, 1990); Stafford, Body Criticism.

14. Martin S. Staum, Cabanis: Enlightenment and Medical Philosophy in the French Revolution (Princeton, NJ: Princeton University Press, 1980); Kathleen Wellman, La Mettrie: Medicine, Philosophy, and the Enlightenment (Durham, NC: Duke University Press, 1992); Antoinette Emch-Dériaz, Tissot: Physician of the Enlightenment (New York: Peter Lang, 1992); C.C. Gillispie, Science and Polity in France at the End of the Old Regime (Princeton, NJ: Princeton University Press, 1980); Matthew Ramsey, Professional and Popular Medicine in France, 1770-1830: The Social World of Medical Practice (Cambridge: Cambridge University Press, 1988); Toby Gelfand, Professionalizing Modern Medicine: Paris Surgeons and Medical Science and Institutions in the Eighteenth Century (Westport, Conn.: Greenwood Press, 1980); the economics of Enlightenment medicine is impressively surveyed in Laurence Brockliss and Colin Jones, The Medical World of Early Modern France (Oxford: Clarendon Press, 1997), chap. 10.

15. Montpellier's preeminent role in eighteenth-century French medicine has been recognized widely by historians; see Paul Hoffmann, La femme dans la pensée des Lumières (Geneva: Slatkine Reprints, 1995): “Les médecins de l'école de Montpellier, dont l'influence est préponderante en France dans la deuxième moitié du XVIIle siècle, ont cherché à définir les lois fondamentales de la nature biologique" (198); Gillispie, Science and Polity: "The Medical University of Montpellier ... exerted a consistently inceptive influence upon the development of French medicine" (217).

16. On medical mechanism, see Thomas S. Hall, History of General Physiology, 600 B.C. to A.D. 1900, vol. 2, From the Enlightenment to the End of the Nineteenth Century (Chicago: University of Chicago Press, 1969), 3-118; François Duchesneau, La physiologie des Lumières: Empirisme, modèles et théories (The Hague: Martinus Nijhoff, 1982), chaps 1-4.

17. Histoire des sciences naturelles, 5 vols (Paris: Fortin, Masson, 1843), 4: 311-24; the title page of this work describes it as "compensée au Collège de France par Georges Cuvier, complétée par M. Magdeleine de Saint-Agy." 
18. Duchesneau, La physiologie des Lumières, 361-430; Elizabeth Haigh, "Vitalism, the Soul, and Sensibility: The Physiology of Theophile Bordeu," JHM 31 (1976): 30-41; id., "The Vital Principle of Paul Joseph Barthez: The Clash Between Monism and Dualism," MH 21 (1977): 1-14; Hall, History of General Physiology, 2: 82-91; a somewhat broader perspective on Montpellier but one that still focuses on the conceptual development of physiology is found in Jacques Roger, Les sciences de la vie dans la pensée française du XVIIle siècle (repr. Paris: Albin Michel, 1993), 618-30. The valuable study of the late Roselyne Rey, Naissance et développement du vitalisme en France de la deuxième moitié du 18 e siècle à la fin du Premier Empire (Oxford: Voltaire Foundation, 2000), became available to me too late to be integrated fully into my own investigation. On certain themes, such as the centrality of practical medicine to the vitalist endeavor, our perspectives converge. On others, especially the position the vitalists occupied within the larger Enlightenment movement, our interpretations differ markedly. I have indicated some points of convergence and divergence in the notes.

19. Reflecting the judgment of d'Alembert and other philosophes, students of Enlightenment science long assumed the dominance of mathematics and the physical sciences; see I. Bernard Cohen, Franklin and Newton: An Inquiry into Speculative Newtonian Experimental Science and Franklin's Work in Electricity as an Example Thereof (Philadelphia: American Philosophical Society, 1956); Robert E. Schofield, Mechanism and Materialism: British Natural Philosophy in an Age of Reason (Princeton, NJ: Princeton University Press, 1969); Thomas L. Hankins, Science and the Enlightenment (Cambridge: Cambridge University Press, 1985); without rejecting the older model, recent work has sought unifying themes less in the methodological and intellectual commitments of Enlightenment science than in its social practice; see The Sciences in Enlightened Europe. For a view of vitalist-inspired science similar to my own, see Peter Reill, "Antimechanism, Vitalism and their Political Implications in Late Enlightened Scientific Thought," Francia 16 (1989): 195-212.

20. Günther Mensching, "La nature et le premier principe de la métaphysique chez d'Holbach et Diderot," Dix-huitième siècle 24 (1992): 117-36.

21. Roger, Sciences de la vie, 641.

22. Despite the recognition of some nuances, this is still the overall perspective of the recent synthesis by Brockliss and Jones, which refers, for example, to "the Enlightenment with its new optimistic and secular value-system that stressed the possibility of change and amelioration"; see The Medical World of Early Modern France, 415.

23. I borrow this phrase from Clifford Geertz, although I use it to refer to a broad-gauge discourse rather than to specific concepts such as the Indic dharma and other features of "legal sensibility" on which he focuses; Clifford Geertz, Local Knowledge: Further Essuys in Interpretive Anthropology (New York: Basic Books, 1983), 183.

24. P.J.G. Cabanis, "Coup d'oeil sur les révolutions et réformes de la médecine," Oeuvres philosophiques de Cabanis, ed. Claude Lehec and Jean Cazeneuve, 2 vols (Paris: Presses universitaires de France, 1956), 2: 143-4.

25. See, especially, the discussion of "official nationalism" as "an anticipatory strategy adopted by dominant groups which are threatened with marginalization or exclusion from an emerging nationally-imagined 
community"; Benedict Anderson, Imagined Communities: Reflections on the Origin and Spread of Nationalism (rev. edn; London: Verso, 1991), 101.

26. For the term "ethnotype," see Michel Peronnet, "Naissance du Midi pendant la Révolution," Historyka 21 (1991): 15-31, at 29; the stereotype of the Midi as the "height of bad taste" and as home to a language that was "mere gibberish" emerged in the seventeenth century both in popular culture and in the screeds of classicists such as Racine, himself a renegade méridional from Uzès; see Alain Corbin, "Paris-Province," Realms of Memory: Rethinking the French Past, vol. 1, ed. Pierre Nora, trans. Arthur Goldhammer (New York: Columbia University Press, 1996), 426-64, at 429.

27. Elizabeth A. Williams, "Physicians, Vitalism, and Gender in the Salon," Studies in Eighteenth-Century Culture, vol. 29, ed. Timothy Erwin and Ourida Mostefai (Baltimore, Md.: Johns Hopkins University Press, 2000), 1-21.

28. Paris developments are the focus in Roger, Sciences de la vie; by contrast, the many works of Louis Dulieu, especially La médecine à Montpellier, 7 vols (Avignon: Les presses universelles, 1975-90; Montpellier, 1994-9), largely ignore Paris; Alisa Reich's "Paul-Joseph Barthez and the Impact of Vitalism on Medicine and Psychology" (Ph.D. diss., UCLA, 1995) is a welcome exception to this pattern; she attends closely to the unfolding of Barthez's career in both locales.

29. The standard historiographical treatment of court life stems from Norbert Elias, The Court Society, trans. Edmund Jephcott (New York: Pantheon, 1983); similarly, until Dena Goodman's breakthrough study, the salon was dismissed as the domain of socially discreet and intellectually timid women rather than as a place for important intellectual or cultural exchange; see Dena Goodman, The Republic of Letters: A Cultural History of the French Enlightenment (Ithaca, NY: Cornell University Press, 1994).

30. Robert Darnton, Mesmerism and the End of the Enlightenment in France (Cambridge, Mass.: Harvard University Press, 1968). 